\title{
Tending operation models for black locust (Robinia pseudoacacia L.) stands growing on sandy soils in Hungary
}

\author{
Rédei, K. ${ }^{1}$, Keserü, Zs. ${ }^{2}$ \& Antal, B. ${ }^{2}$ \\ ${ }^{1}$ NARIC-Forest Research Institute \& Hungarian Horticultural Propagation Material Non-profit Ltd., \\ Sárvár-Budapest \\ ${ }^{2}$ NARIC-Forest Research Institute, Experimental Station,Püspökladány, Hungary; \\ correspondence: redei.karoly@t-online.hu
}

\begin{abstract}
Summary: A more intensive integrated research and development approach to the work carried out on the growth on sandy soils of stands of black locust (Robinia pseudoacacia L.) has been adopted in recent years, revealing several factors influencing stand growth. The fact that certain ecological factors influencing fundamentally the growth of trees have become unfavourable in Hungary in recent years has led to the more extensive use of black locust in the course of afforestation and forest regeneration schemes. The study presents a new, simplified tending operation model for black locust stands and age, growing space and target diameter models suitable for qualitaty log production and for mass assortments. The simplicity of these practice-oriented models may foster the qualitative development of black locust management in Hungary and in some other countries where this tree species may gain greater acceptance by landowners and the forest industry.
\end{abstract}

Keywords: black locust (Robinia pseudoacacia L.), silviculture, growing place, target diameter

Black locust (Robinia pseudoacacia L.) is one of the most important exotic stand-forming tree species in Hungary. Due to its favourable silvicultural and growth characteristics, as well as the possibilities for the utilisation of its wood, the area it occupies is increasing continuously (Keresztesi,1988). The most important task facing Hungarian black locust growers is to improve the quality of its stands for wood production (Rédei et al., 2002). The area occupied by black locust in 2015 was 465000 ha $(23.8 \%$ of the total forest area), with a standing volume of 48.1 million $\mathrm{m}^{3}$ (13.4\% of the total) . Its importance will continue to increase across the large areas of marginal land not suitable for the native tree species but able to accommodate black locust. Other species that may be used for the purposes of plantation forestry in addition to black locust are poplar species, red oak and black walnut. Common walnut plantations may also play a role, but the silvicultural significance of this tree species is negligible.

Black locust plantations and stands can be successfully established in response to a range of ecological and economic opportunities. Plantation survival and productivity are maximized by matching the species' growth characteristics with silvicultural options and land management needs (Rédei, 1992, 2001). From among the above listed tree species, the models for tending operations and the tables for age-growth space-target diameter models are suitable for production of large, quality wood material as well as mass assortments produced in black locust stands.

\section{Material and methods}

\section{Materials}

The models developed are based on a yield table for black locust (Rédei, 1984, 2003). It was constructed from data gathered from 150 permanent and 50 temporary yield study sample plots $\left(500-1000 \mathrm{~m}^{2}\right)$. The stands sampled were located in the vicinity of $\mathrm{N} 45^{\circ} 48^{\prime}$ to $48^{\circ} 35^{\prime}$ and $\mathrm{E} 16^{\circ} 5^{\prime}$ to $22^{\circ} 58^{\prime}$. The age of the stands varied between 5 and 45 years.

\section{Methods}

The following parameters were measured and calculated: number of stems, dbh (diameter at breast height), basal area, tree height, stem volume and stand volume. The stem volume was calculated using the volume function based on the volume table for black locust (Sopp and Kolozs, 2000):

$$
v=10^{-5} d^{2} h^{1}(h /[h-1.3])^{2}(-0.6326 d h+20.23 d+3034) \text {. }
$$

where $v$ is stem volume (m3), $d$ is diameter at breast height $(\mathrm{cm})$ and $h$ is tree height (m).

The collected data were analysed using STATISTICA 8.0 software (StatSoft Inc.), i.e., correlation and regression analysis. The yield model was constructed using the following formulas and coefficients (Rédei 2003, Rédei et al. 2011). 
1. $\mathrm{A}=$ age of stand in years

$\mathrm{H}=$ mean height of the main crop weighted by the basal area $(\mathrm{m})$.

$\mathrm{H} \%=123.12\left(1-\mathrm{e}^{-0,070333 \mathrm{~A}}\right)^{1.111638}$,

with $\mathrm{R}=0.995$.

$\mathrm{H}$ at the age of $25=100 \%$. The expected height values

of the main stands at the

reference age according to the six yield classes are:

$23.8 \mathrm{~m}, 21.3 \mathrm{~m}, 18.8 \mathrm{~m}, 16.3 \mathrm{~m}, \mathrm{~m}$ and $11.3 \mathrm{~m}$.

2. $\mathrm{DBH}=$ the diameter at breast height of the main crop

(cm):

$\mathrm{DHB}=(69.9675+1.00625 \mathrm{~A})$
with $\mathrm{R}=0.809$

3. $\mathrm{N}=$ number of stems per hectare of the main crop:

$\mathrm{N}=\mathrm{e}^{9.81801-1.15147 \times \ln \mathrm{DBH}}$

with $\mathrm{R}=0.942$

\section{Results}

\section{Simplified tending operation model for black locust stands}

The black locust is a fast-growing tree species, which, up to the age of 10-15 years, is able to quickly close canopy openings caused by tending operations, but the closure is much slower in later years. Height growth peaks within the first five years, while diameter growth peaks in the first decade. The peak of current annual increment is at about age 20 , whereas that of the mean annual increment is at about age 35-40. To find the right cleaning and thinning intensity, the so-called growing space index is a good method. This index expresses the mean distance between trees (in a triangular pattern) as a percentage of mean height after cleanings and thinnings. The mean value of the index for black locust stands should be $23-24 \%$. Pruning of crop trees should also be carried out. After finishing selective thinnings, stems must be free of branches up to a height of 4-6 m (Rédei 2003).

Table 1 contains a simplified tending operation model for black locust stands. The table was compiled using data obtained from 80 long term yield and experimental tending operation plots. The choice of the most suitable spacing depends on the quality of the planting material and the particular site conditions. In the table, all of the data are presented by six yield classes. Yield (site) index curves are commonly used in forestry to quantify yield (site) quality differnces. This method uses mean tree height of the main crop which is the most important model factor, because it determines the timing of the particular tending operation. Thinnings (to expand the available growing space) must be carried out when the stocking density approaches the stem number quoted in the table.

The objective of tending is to produce a high proportion of good quality sawlogs from stands of yield class I and II; some sawlogs and a high proportion of poles and props from stands of yield class III and IV; and poles, props and other smell-dimension industrial wood from other yield stands. Tending operations for stands of selected black locust varieties have not yet been elaborated. Based on investigation results gained up to now, on good sites the stoking at final felling could be 500 to 600 trees per hectare, where the initial tree density was 2000 to 2500 stems per hectare. The tree density for final felling (35 to 40 years) can be attained by two thinnings. On medium good sites the initial tree density may be 3500 to 4000 stem per hectare and at felling age it may be reduces to 900 to 1000 per hectare at the at the age of 25 to30 (Rédei 2003).

Tabla 1: Simplified tending operation model for black locust stands

\begin{tabular}{|c|c|c|c|c|c|c|}
\hline \multirow{3}{*}{$\begin{array}{c}\text { Tending } \\
\text { operation }\end{array}$} & \multirow{3}{*}{$\begin{array}{c}\text { Number } \\
\text { of } \\
\text { tending } \\
\text { operation }\end{array}$} & \multicolumn{3}{|c|}{ Tending operation } & \multirow{2}{*}{\multicolumn{2}{|c|}{$\begin{array}{c}\begin{array}{c}\text { Stocking density } \\
\left(\text { stems ha }^{-1}\right)\end{array} \\
\text { Tending operation }\end{array}$}} \\
\hline & & \multirow{2}{*}{$\begin{array}{l}\text { To be } \\
\text { carried } \\
\text { out in } \\
\text { year... }\end{array}$} & \multirow{2}{*}{\multicolumn{2}{|c|}{$\begin{array}{c}\text { To be carried out at } \\
\mathrm{H}_{\mathrm{m}}(\mathrm{m}) \text { and } \\
\text { yield class... }\end{array}$}} & & \\
\hline & & & & & before & after \\
\hline \multirow{2}{*}{ Cleaning } & 1. & $5-8$ & $6-7$ & I-V (VI) & $>3500$ & $\begin{array}{l}2500- \\
2700\end{array}$ \\
\hline & 2. & $9-13$ & $11-12$ & I-IV & $\begin{array}{l}2500- \\
2700\end{array}$ & $\begin{array}{c}1500- \\
1600\end{array}$ \\
\hline \multirow{2}{*}{ Thinning } & 1. & $14-19$ & $15-16$ & I-IV (V) & $\begin{array}{c}1500- \\
1600\end{array}$ & $\begin{array}{l}700- \\
800\end{array}$ \\
\hline & 2. & $22-24$ & $21-22$ & I-III & $\begin{array}{c}700- \\
800\end{array}$ & $\begin{array}{c}450- \\
550\end{array}$ \\
\hline \multirow[t]{2}{*}{$\begin{array}{l}\text { Final } \\
\text { cutting }\end{array}$} & & $\begin{array}{c}35-40 \\
30\end{array}$ & & $\begin{array}{l}\text { I-II } \\
\text { III-IV }\end{array}$ & - & $\begin{array}{c}400- \\
500 \\
600- \\
700\end{array}$ \\
\hline & & $\begin{array}{c}25 \\
(20) \\
\end{array}$ & & $\begin{array}{c}\mathrm{V} \\
\text { (VI) }\end{array}$ & - & $\begin{array}{l}(<1000) \\
(<1300) \\
\end{array}$ \\
\hline
\end{tabular}

Remarks for the use of the tending operation model: When planning the thinning operation, the better the estimated yield class, the lower the stem number value after thinning to be applied. Black locust stands in yield classes V-VI are not suitable for quality wood production. The thinning 2 is not to be carried out in these stands.

In plantation forestry the timing of the expansion of the available growing space is significant with respect to reaching the target assortments by maintaining the near optimal stocking density per hectare (growth space). The site (ecological) factors essentially define the target assortments; for example, whether the opportunity for the production of sizeable, quality wood material (panel log, sawlog) exists or merely thinner wood assortments (cutting, pallet and box basic material), pulp, fibre, chippings and basic wooden board materials.

The data in Table 2 show that an opportunity for the production of quality, sizeable logs is possible in black locust poplar stands classified yield class I to III. For black locust stands in yield class IV - assuming an average harvesting age of 30 years - a target diameter of 18 to $20 \mathrm{~cm}$ can be planned with great certainty. The sustainable stocking density per hectare depending on the yield class varies from 450 to 660 stems per hectare.

The table also shows that stands of yield classes IV and $\mathrm{V}$ are suitable for the production of mass assortments, and possibly even black locust stands of yield class VI with a target diameter of 10 to $12 \mathrm{~cm}$. However, the management of stands characterised by these two lowest yield classes are 
usually loss producing and so are unsuitable for plantation forestry.

Black locust stands growing under unfavourable ecological conditions also have an earlier harvesting age (generally between 25 and 30 years). The sustainable stocking density varies between 1100 and 1800 stems per hectare depending on the yield class. In these stands - based on our yield studies - the reduction in stem number (thinning) carried out at age 15 to 17 does not lead to a significant increase in diameter growth.

Table 2: Age-target diameter model for black locust stands targeted for quality sawlog production $(\mathrm{DBH}=18,20$ and $25 \mathrm{~cm})$ and for mass assortments $(\mathrm{DBH}=10,12,14$ and $16 \mathrm{~cm})$

\begin{tabular}{|c|c|c|c|}
\hline \multirow[b]{2}{*}{$\begin{array}{l}\text { Planned target } \\
\text { diameter }(\mathrm{DBH}) \\
(\mathrm{cm})\end{array}$} & \multicolumn{3}{|c|}{ Factors } \\
\hline & Yield class & $\begin{array}{c}\text { Years required } \\
\text { to reach target } \\
\text { diameter }\end{array}$ & $\begin{array}{l}\text { Stocking density } \\
\text { (stems per ha) }\end{array}$ \\
\hline 25 & $\mathrm{I}$ & 21 & \multirow{2}{*}{$450 \pm 5 \%$} \\
\hline 25 & II & 25 & \\
\hline 20 & $\mathrm{I}$ & 16 & \multirow{3}{*}{$590 \pm 5 \%$} \\
\hline 20 & II & 18 & \\
\hline 20 & III & 23 & \\
\hline 18 & I & 14 & \multirow{3}{*}{$660 \pm 5 \%$} \\
\hline 18 & II & 17 & \\
\hline 18 & III & 21 & \\
\hline 16 & IV & 26 & \multirow{3}{*}{$1150 \pm 5 \%$} \\
\hline 16 & $\mathrm{~V}$ & - & \\
\hline 16 & VI & - & \\
\hline 14 & IV & 22 & \multirow{3}{*}{$1310 \pm 5 \%$} \\
\hline 14 & $\mathrm{~V}$ & 27 & \\
\hline 14 & $\mathrm{VI}$ & - & \\
\hline 12 & IV & 18 & \multirow{3}{*}{$1530 \pm 5 \%$} \\
\hline 12 & $\mathrm{~V}$ & 22 & \\
\hline 12 & VI & 32 & \\
\hline 10 & IV & 10 & \multirow{3}{*}{$1840 \pm 5 \%$} \\
\hline 10 & $\mathrm{~V}$ & 16 & \\
\hline 10 & VI & 22 & \\
\hline
\end{tabular}

Silviculture has been defined as the art of producing and tending a forest. As scientific silvicultural principles are developed, and as the likelihood of success increases, hardwood plantation production will become more attractive.

Black locust plantation management for improved growth is becoming ever more significant in lowland forestry. This fact was partly taken into account in the conception of this study, and fed into the novel planning tools developed to help increase the value of the material produced in black locust stands. In recent decades, growth models based on stand level data have gradually been replaced by stand growth models predicated on stem number frequencies and individual tree growth models. Nevertheless, traditional tending operation models will remain very useful tools for forest management and forest inventory. The published models can be used in black locust management and forest inventory, such as:

- statistical appraisal of black locust stands (according to yield classes),

- harvest scheduling for black locust stands,

- further development of silvicultural (tending operation) models for black locust stands, and

- growth and economic analises of black locust stands.

On global basis, the black locust has been extensively planted in some Asian countries (Turkey, China, Korea) for various purposes, such as fuel, forage, honey production, soil erosion control, windbreak and landscap. Recently, the usefulness of black locust in timber production and agriculture has been newly recognized by some European and South-American countries as well, which has promoted new introduction and research on black locust.

\section{References}

Keresztesi, B. (1988): The Black Locust. Akadémiai Kiadó, Budapest.

Rédei, K. (1984): Yield of black locust stands in Hungary. Research Report. Forest Research Institute, Budapest.

Rédei, K. (1992): Management of Black Locust Stands in Hungary. Proceedings: Internatinal Conference on Black Locust. East Lansing (MI), 38-43.

Rédei, K. (2001): The main characteristics of black locust (Robinia pseudoacacia L.) mangement in Hun gary. Third Balcan Scientific Conference. Proceedings, Sofia, 293-300.

Rédei, K., Osváth-Bujtás, Z., Lee, J. (2002): Selection and management of black locust (Robinia pseudoacacia L.) in Hungary for timber and honey production and landscape. Journal of Korean Forestry Society, 91:156-162.

Rédei, K. (2003): Black Locust (Robinia pseudoacacia L.) Growing in Hungary. Publications of the Hungarian Forest Research Institute, Budapest.

Rédei, K., Csiha I., Keserü Zs., Kamandiné Végh Á., Rásó, J. (2011): Local volume table of black locust (Robinia pseudoacacia L.) stands growing in the Nyírség region (in Hungarian). Erdészettudományi Közlemények, 1: 115-124.

Sopp L., Kolozs L. (2000): Volume tables. Budapest. Agricultural Publishing House. 